\title{
Additivity and Complementarity in External Technology Sourcing: The Added Value of Corporate Venture Capital Investments
}

\author{
Vareska van de Vrande, Wim Vanhaverbeke, and Geert Duysters
}

\begin{abstract}
Innovating firms often invest in a number of different technology projects, in different stages of development, using a wide range of distinct technology sourcing modes, such as strategic alliances, joint ventures, and mergers and acquisitions. Recently, firms have also gained an increasing awareness of the potential benefits of corporate venture capital investments. This paper investigates the particular role of corporate venture capital investments in the technology sourcing portfolio of firms. More specifically, we focus on the extent to which corporate venture capital investments are additive or complementary to other modes of technology sourcing when explaining the innovative performance of firms. The results indicate that corporate venture capital investments are particularly beneficial for the innovative performance of firms when they are used in combination with other technology sourcing modes.
\end{abstract}

Index Terms-Complementarity, corporate venture capital investments, external technology sourcing, M\&As, open innovation, strategic alliances.

\section{INTRODUCTION}

$\mathbf{O}$ VER the past years, companies have started to open up their innovation process [14], [16], [53]. As a consequence, the external acquisition of knowledge has become a central part of firms' corporate strategy. Rather than making ad hoc investments in external technology acquisition, the innovation strategy of firms nowadays is more likely to follow a portfolio approach to the external sourcing of technologies. An increasing number of authors have called for an integrated perspective on external technology sourcing in order to account for the interrelationships that exist among technology sourcing modes [8], [48], [63]. Using a portfolio approach allows innovating firms to spread their investments along a broader range of technology projects, in different stages of development. This also implies that firms use a variety of technology sourcing

Manuscript received April 20, 2010; revised August 21, 2010 and September 30, 2010; accepted October 19, 2010. Date of publication March 28, 2011; date of current version July 20, 2011. Review of this manuscript was arranged by Department Editor C. Tucci.

V. van de Vrande is with the Department of Strategic Management and Business Environment, Rotterdam School of Management, Erasmus University, 3000 DR Rotterdam, The Netherlands, and with the Ecole Polytechnique Federale de Lausanne, 1015 Lausanne, Switzerland (e-mail: vvrande@ @rsm.nl).

W. Vanhaverbeke is with the Hasselt University, 3590 Diepenbeek, Belgium, and with Vlerick Leuven Gent Management School, Leuven, Belgium, and also with ESADE Business School, 08034 Barcelona, Spain (e-mail: wim. vanhaverbeke@uhasselt.be).

G. Duysters is with the University of Tilburg, 5000 LE Tilburg, The Netherlands, and with the Eindhoven University of Technology, 5600 MB Eindhoven, The Netherlands (e-mail: g.m.duysters@tue.nl).

Digital Object Identifier 10.1109/TEM.2010.2091134 mechanisms to target these different types of resources. In the past, strategic alliances and M\&As have received a lot of attention in the literature as mechanisms to spur the innovative performance of firms. More recently, another type of technology sourcing has emerged: corporate venture capital (CVC) investments. CVC investments are minority equity investments in young, start-up firms, and during recent years, these types of investments have received increased attention both in business as well as in academia (e.g., [20], [21], [82]).

Prior studies focusing on the relationship between CVC investments and innovative performance have shown that CVC investments have a positive effect on the subsequent patenting rates of investing firms (e.g., [21]). However, the explanation of these studies on the benefits of CVC investments is limited to a certain extent. After all, most large diversified companies do not limit their sourcing strategies to one or two technology sourcing modes. They rather set up a portfolio of innovation projects ranging all the way from more incremental to high-risk, radical innovations. To cover this broad range of innovation projects, firms use a variety of distinct sourcing modes, each with its own characteristics, advantages, and management challenges. Thus, in order to fully explain the effect of CVC investments on innovative performance, it is important to include a more comprehensive set of technology sourcing modes that are used by these firms. Nevertheless, the role of CVC investments within the technology sourcing portfolio of firms has been largely unaddressed in prior research (notable exceptions are [50] and [70]).

In response to this research gap, the current study examines the effect of using multiple sourcing strategies on a company's subsequent innovative performance. Although the focus is on a broad array of external technology sourcing modes, particular attention will be paid to the added value of CVC investments. Because CVC investments are likely to be used next to the more traditional modes for external technology sourcing, we argue that the effects of CVC investments cannot be estimated by looking at them in isolation. In fact, the actual benefits of CVC investments are likely to be dependent on the overall sourcing portfolios of firms. Therefore, this paper focuses on the complementarity between CVC investments on the one hand, and strategic alliances and M\&As on the other hand, when explaining the innovative performance of firms. Although prior studies have looked at complementarity effects of external technology sourcing (e.g., [5], [8], and [12]), they have not yet explicitly linked the nature of the interaction between CVC investments and other technology sourcing modes to innovation. We argue that CVC investments are additive to other modes of external 
technology sourcing, because they all target different types of knowledge. Additionally, we argue that CVC investments are complementary to the other technology sourcing modes because of the knowledge and experience spillovers associated with external knowledge acquisition.

As such, this paper contributes to the literature in two ways. First, as discussed earlier, we incorporate a broader set of technology sourcing modes that can be used to source technologies externally and thereby may increase the innovative performance of companies. By discussing and empirically testing the combined effects of nonequity alliances, equity alliances, M\&As, and CVC investments on the innovative performance of firms in one single model, this paper adds to the increasing body of research into portfolio management and alliance portfolios in particular (e.g., [59] and [63]). Second, since CVC investments have become a popular way to access external knowledge, this paper shows whether and to what extent this type of investment serves as a complement to other external sourcing strategies for improving firms' innovative performance.

The remainder of this paper is organized as follows. First, we will discuss the role of external knowledge acquisition in explaining the innovative performance of firms. We will pay particular attention to the effects of corporate venture capital investments in combination with investments in strategic alliances and M\&As. Second, we will discuss the concepts of additivity and complementarity, explaining why corporate venture capital is not only additive to other modes for technology sourcing but also complementary. Next, we will empirically test our hypotheses using a panel dataset of external sourcing behavior of innovating firms. Finally, in Section V, we will present and discuss the results and indicate how future research can build upon the conclusions of this study.

\section{BACKGROUND}

\section{A. External Knowledge Sourcing and Innovation}

Companies that have decided to source knowledge externally can choose between a broad range of technology sourcing modes that they can employ for that purpose. Researchers have studied the impact of different external modes on the innovation performance of companies. Several studies have focused on the effect of CVC (e.g., [82]), equity and nonequity alliances (e.g., [72]), and M\&As (e.g., [2]) on firms' innovation performance. However, even studies that consider two modes to acquire external technology tend to examine them independently. In turn, we consider these different sourcing modes simultaneously and study whether a portfolio with a diversified set of different external technology acquisition modes leads to superior technological performance compared to firms that rely heavily on one mode to source external technology.

\section{B. Technology Alliances and Acquisitions}

Traditionally, mergers and acquisitions have been regarded as the primary way for companies to grow and to obtain additional resources. When sourcing external ideas through a merger or acquisition, the acquired resources are internalized in the investing firm. Thus, the resources obtained are accumulated to or integrated with the resources that were already present. The general assumption is that through economies of scope and scale, this enlarged bundle of resources makes more efficient production possible and should thus have a positive impact on firm performance [58]. In addition, M\&As are likely to increase innovative capabilities of the acquirer because they raise the overall $R \& D$ budget [19]. Moreover, technology buying might speed up the capability process because a firm instantly gets access to technology instead of having to develop it from scratch.

Despite these apparent advantages, prior research has shown mixed results for the overall effect of M\&As on the investing company's innovative performance. For example, Hitt et al. [42] found a negative relationship between $R \& D$-related acquisitions and patent intensity, whereas others found positive effects depending on the nature of the M\&As under study. Ahuja and Katila [2] point toward the fact that nontechnological acquisitions are likely not to provide technological inputs and hence, cannot be expected to increase the innovative output. In a similar vein, other studies revealed positive effects only for related M\&As [35], [81].

Although M\&As are still a popular way for firms to achieve growth, less integrated forms of technology sourcing have also gained ground. Strategic alliances, such as nonequity R\&D agreements and joint ventures, have become more important vehicles for knowledge acquisition during the last two decades. Strategic alliances can roughly be described as "cooperative efforts in which two or more separate organizations, while maintaining their own corporate identities, join forces to share reciprocal inputs [80] and can be divided into equity and nonequity alliances [44], [84]. Equity alliances involve the transfer of equity, for instance, through the creation of a new organizational entity (joint venture), whereas nonequity alliances do not require the use of equity investments. Despite the possible risks that are associated with strategic alliances, such as free-riding and opportunistic behavior [32], the main advantage of strategic alliances and joint ventures as opposed to M\&As is the sharing of costs and risks, which makes them particularly attractive in turbulent environments. Sharing the costs and risks connected to $R \& D$ with a partner can be regarded to as an effective way to manage the uncertainty surrounding this process [33]. Besides, strategic alliances allow the partners to access only part of each others' resources, which is especially valuable when not all the resources possessed by the partner are sought after by the investing firm [17]. Additionally, strategic alliances are also more flexible than M\&As. Withdrawing from a strategic alliance or joint venture is not as complicated and costly as it might be to divest a prior acquisition. This makes strategic alliances a more viable alternative to $M \& A s$ in order to cope with the uncertainty of R\&D in earlier stages of the new business development process, when the technology and its potential rewards are not yet fully known.

There are a number of reasons why it can be argued that strategic alliances spur innovation. In particular, strategic alliances provide the ability to share costs and risks, to integrate complementary knowledge, and to aim at specific pieces of knowledge [19]. Their review of prior empirical studies shows 
a strong, positive effect for strategic alliances on innovative performance [19]. In addition, Stuart [72] finds a positive effect between strategic alliances with large and innovative partners and innovation improvement and growth rates, and Baum et al. [7] find that the number of alliances positively affects the success of biotech start-ups.

\section{Corporate Venture Capital Investments}

A strategy that has received growing attention more recently among researchers and practitioners alike is the use of corporate venture capital. Corporate venture capital (CVC) emerged in the 1960s and can be defined as "equity investment by incumbent firms in independent entrepreneurial ventures, i.e., relatively new, not publicly traded companies that are seeking capital to continue operation" [28]. Although this definition is broad and may include many types of interorganizational ties, it should be noted that there are three aspects that distinguish a CVC investment from a strategic alliance. First of all, the notion of CVC investments focuses specifically on venture capital investments. Venture capital investments are usually high-risk investments in high-tech start-ups. They are typically structured through a dedicated venture capital fund, in a number of rounds, and with a number of coinvestors. Second, managers consider CVC investments and alliances as distinct activities that have to be managed in different ways: corporations set up a separate, dedicated organizational entity with allocated funds to invest in interesting ventures [13], [14]. Strategic alliances on the other hand, are often governed by an alliance management department at the corporate level, but also in many cases, managed at the divisional or business unit level [23], [40], [55]. Third, strategic alliances imply that the otherwise independent partners become mutually dependent through their resource commitments in joint $R \& D$. In a technology alliance, partners strive toward shared objectives and try to maximize the financial return from their collaboration. In contrast, in CVC investments, the investing company has different objectives than the management team of the portfolio firm: the investor invests unilaterally in the portfolio firm and claims in return several rights.

Prior research has indicated that the motives for companies to invest in entrepreneurial start-ups range from purely financial objectives (i.e., return on investment) to more strategic motivations, such as identifying possible acquisition targets and obtaining a window on new technologies [24], [49], [71], [74]. As shown in a study by Kortum and Lerner [52], venture capital activity has significant, positive impact on the patenting rates of industries, stressing the role of venture capital to spur innovation in general. From an investing firm's perspective, CVC investments are particularly interesting to contribute to the firm's innovation output, because they enable them to get access to technologies in an early stage of development, when it is still too risky to establish equity alliances such as joint ventures. $\mathrm{CVC}$ investments can also serve as a window on emerging technologies. In that case, it is not even appropriate to establish strategic alliances until it becomes clear that the technology of the portfolio firm might have some commercial potential for the corporate investor.
Because CVC investments are specifically targeted at young, privately held companies [28], they provide the investing firm with access to a source of knowledge that might be difficult to target through M\&As or strategic alliances. Moreover, these new ventures are an important source of innovative ideas that still need to be further developed or commercialized. Therefore, getting access to these ideas and technologies at this stage provides the investing firm with a possible vital source of competitive advantage. After all, breakthrough inventions often come from new, pioneering technologies [3]. Additionally, it should be noted that CVC investments are a flexible instrument to invest in new technologies with unknown future potential. This allows companies to invest in different, even competing technologies, with potentially high but also highly uncertain returns. CVC investments allow the investing company to defer irreversible investments until new information about the economic viability of a technology becomes available. Using less flexible modes of technology sourcing such as equity alliances and acquisitions in this phase might lead to long-term commitments to technologies that in the end prove not to be viable. CVC investments allow firms to "explore" a broad range of promising technologies while not overcommitting themselves to specific technological trajectories.

A number of prior studies have examined the effect of corporate venture capital investments on the performance of the investing company. Dushnitsky and Lenox [21] found a positive relationship between CVC investments and future patent citation levels, whereas Wadhwa and Kotha [82] found an inverted U-shaped relationship between CVC investments and the subsequent patent applications rate of investing firms. In addition, Gompers [27] finds that the success rate of CVC investments within the same industry is larger than the success rate of nonrelated CVC investments, which is partially supported by the findings of Keil et al. [50]. In a study on the effects of intraindustry, related and unrelated CVC investments, they found a significant, positive effect for related CVC investments only. In addition, Dushnitsky and Lenox [22] showed that CVC investments that focus specifically on strategic outcomes provide greater firm value than financially focused CVC investments.

To summarize, CVC investments are targeted at young, entrepreneurial ventures that are generally regarded as an important source of innovative ideas. Getting access to these emerging technologies provides the investing firm with a viable source of competitive advantage, leading to increased innovation performance. However, as noted earlier, most established, innovative firms do not limit their sourcing strategies to one mode in particular. Rather, they invest in a portfolio of technology sourcing partnerships. Therefore, it is not sufficient to study the effects of CVC investments in isolation, as the innovation output of the investing firms might also be the result of other external knowledge sourcing partnerships. Hence, by neglecting the impact of other sourcing modes, the effect of CVC investments is likely to be estimated incorrectly as a result of an omitted variable bias. Consequently, we hypothesize:

Hypothesis 1. The positive effect of CVC investments when studied in isolation is overestimated due to an omitted variable bias. 
In order to estimate the true benefits of CVC investments on innovative performance, they should therefore be studied in relation to the other strategies for external technology sourcing that are used simultaneously.

\section{Additivity of CVC Investments}

Prior studies on the relationship between external technology sourcing and innovation have found ample evidence that external sourcing of knowledge positively affects innovation output of investing firms. However, this evidence might be biased to some extent, as the innovative performance of firms may not necessarily be the result of investing in one particular technology sourcing mode, but rather the combined effect of multiple types of external technology sourcing modes. In order to overcome this potential omitted variable bias, it is important to look at the investment portfolio of firms. One of the ways to do so is by estimating the additivity of different technology sourcing modes. By additivity, we mean that the combined effect of two or more activities is equal to the sum of the effects of each of these activities separately. For two strategies, this can be represented by the following function: $f(x, y)=f(x)+f(y)$. When applying this to the notion of external technology sourcing, we suggest that the total innovative performance of firms is a linear function of the different technology sourcing modes a firm undertakes.

After all, CVC investments, strategic alliances, and M\&As serve the same overall purpose: getting access to external knowledge to strengthen a firm's technological capabilities and performance. However, despite this commonality, they all have different characteristics as mentioned before, and consequently, they can be used to target different types of knowledge or knowledge in different stages of development. We argue that the simultaneous use of different external sourcing modes helps firms improve their innovation performance. The additivity of different external sourcing modes is in line with the open innovation imperative [14]: innovating firms can improve their innovativeness when they tap into different types of external knowledge along the innovation funnel. Innovating firms should not only collaborate with universities and research labs on new scientific discoveries that still have to go a long way before they hit the market, but they should also get involved in CVC, codevelopment with partners, spin-ins, and technology acquisitions. On the one hand, companies have to source external technologies to strengthen their current businesses, but on the other hand, they also need to generate completely new businesses. Firms can thus benefit from sourcing concurrently different types of knowledge.

Innovating firms thus have to get involved in different sourcing modes at the same time as each sourcing mode will allow the company to source a particular type of knowledge. For instance, due to the irreversible nature of M\&As, they are less attractive in the early phases of development, when the potential value of the technology is still highly uncertain. Strategic alliances are more flexible, and they are also valuable for sharing of costs and risks, which makes them more suitable for codeveloping new technologies. In this sense, strategic alliances and M\&As can serve as an additional way to source new technologies within the context of new business development. In turn, CVC investments are especially valuable to target knowledge that is in an early stage of development and which is often privately held. Because these kinds of technologies might be more difficult to target through an acquisition or through the use of strategic alliances, CVC investments can play an important role here. Moreover, even when a strategic alliance or M\&A is a viable sourcing mode, they may be less attractive because they do not have the desired level of flexibility.

Several scholars ([78], [79], [86]) have argued that in the face of high technological and commercial uncertainty, firms are likely to delay their investments in certain technologies. In this case, they make small investments in a certain technological field in order to build familiarity with this new field. A recent survey [60] has shown that CVC investments are typically made in earlier-stage technologies or in technologies that are noncore to the company. Given the fact that different technology sourcing modes are effective in targeting different technologies or innovation stages, one can expect that firms will benefit from establishing different types of sourcing modes resulting in a diversified portfolio of channels to tap into external technology. Furthermore, not only technological uncertainty is important in this context but also endogenous uncertainty arising from the dissimilarities among partners plays a role in technology sourcing mode choice [78]. For example, in the case of dissimilar technology bases, firms are likely to opt for CVC investments over strategic alliances and M\&As. Hence, different governance modes play a different role in the external sourcing of technology, depending on aspects such as the stage of development of the technology and the level of uncertainty surrounding the investment decision. Being involved in a broader portfolio consisting of different types of technology sourcing modes is therefore an important way for innovating companies to get access to various types of knowledge in different stages of development. In the long run, being involved in different strategies that cover the various stages in the technology development funnel enhances the variety of technologies that is invested in, thereby increasing the innovative performance of the firm [7], [66].

Consequently, engaging in different types of external technology sourcing modes is an important way for firms to improve their innovative performance. Companies will optimally profit from external sources of technology when they can tap into external technology at the right stage of their development. Depending on a firm's innovation strategy and the type of external knowledge, it might choose to be involved early on in a technology development or it might wait until the technology is further developed and has proven to be a commercially valuable technology. Hence, firms need different types of external technology sourcing modes to assimilate knowledge in different stages of development. Investing in CVC investments, next to strategic alliances and M\&As, will therefore increase the innovative output of investing firms. Thus, we hypothesize:

Hypothesis 2. Corporate venture capital investments are additive to other modes of external technology sourcing. 


\section{E. Complementarity of CVC Investments}

Besides the additivity of different technology sourcing modes, another interesting aspect is whether different technology sourcing modes are complementary to each other. The notion of complementarity is closely related to the concept of superadditivity or supermodularity [61]. Supermodularity occurs when "adding an activity while already performing the other activity has a higher incremental effect on performance than when doing the activity in isolation" [12]. Mathematically, this can be represented as: $f(x, y) \geq f(x)+f(y)$. The two activities $x$ and $y$ can then be regarded as complements. In practice, the forces of both additivity and complementarity can work at the same time. Additivity indicates that innovating companies benefit when they deal simultaneously with technologies that are in different stages of development (see Hypothesis 2), whereas complementarity arises from reputational effects, and knowledge and experience spillovers between the different sourcing modes.

With respect to different technology sourcing modes used for external technology sourcing, complementarity means that there is a symbiotic relationship between the different technology sourcing modes and that their joint effects on a firms' innovation performance is stronger than their sole effects. Actually, the notion of complementarity suggests that each technology sourcing mode not only has a direct effect on the innovative output, but that each technology sourcing mode also positively affects the relationship between other technology sourcing modes and the innovative performance of firms. The complementarity between CVC investments and other technology sourcing modes can result from different drivers. We first focus on knowledge spillovers as well as experience spillovers. First, CVC investments enable learning about new technological knowledge, which increases the absorptive capacity of firms. By making small investments in entrepreneurial start-ups, investing firms gradually expand their technological knowledge base, and consequently, also expand their absorptive capacity. This increased absorptive capacity improves the extent to which the firm is able to recognize, assimilate, and exploit the technological knowledge obtained through the use of other technology sourcing mechanisms. A broad portfolio of technology sourcing modes can allow firms to draw knowledge from multiple external sources, thereby providing them with information advantages and knowledge spillover effects. Ties to a large number of different sources might provide firms with the opportunity to better assess the specific value of the knowledge gained from a particular technology sourcing mode. This process of triangulation [26] is seen as an important aspect of assessing information with a high novelty value. As a result, we can expect that the required knowledge to source external technology effectively through strategic alliances, for instance, is leveraged by the existing CVC investments and vice versa.

In addition, recent work [4], [18], [39], [69] has shown that prior engagement in strategic alliances can lead to future success because experience helps firms to gain knowledge about critical processes and issues in dealing with alliances. Similar reasoning applies to CVC investments and M\&As. Through experience, firms accumulate a collective understanding of the ex- ecution of organizational tasks involved with external sourcing of knowledge, which, in turn, leads to more refined and efficient processes over time [84]. As a result, there are learning effects from external knowledge sourcing that enable firms to be more efficient in using external acquisition modes [39]. Similarly, making small, learning investments made through CVC investments may also lead to experience spillovers [85]. This implies that by experimenting with CVC investments, the investing firm creates management skills in the recognition, absorption, and assimilation of external knowledge, which can also be applied to other governance modes in the technology sourcing portfolio. Overall, this increased external sourcing experience would be beneficial to the whole sourcing portfolio, as it also enhances the effectiveness and efficiency with which knowledge is being targeted and transferred through other governance modes.

The complementarity of different sourcing modes should, however, not be limited to knowledge and experience spillovers. Different external sourcing modes also provide access to complementary resources [20]. Arora and Gambardella [5] argued that one type of external resource frequently increases the need for other types. For example: car manufacturers who invest in technology savvy start-ups to come up with new hybrid cars will also have to establish technology alliances with battery manufacturers. As complementarity of external resources is associated with each type of external sourcing modes, we can expect that higher technological performance will result from the combination of different external technology sourcing modes. In addition, having more alliances, acquisitions, and CVC investments provide also greater visibility and prominence to the innovating firms. When a company invests in several CVC investments and has the reputation to be a reliable and trustworthy investor, it will have an advantage in establishing new technology alliances or to negotiate an acquisition of high-tech startups. But also the opposite is true: a firm may leverage its alliance network and track record of high-tech acquisitions to enhance visibility among the $\mathrm{VC}$ community in order to legitimize new CVC investments. Consequently, firms that rely on visibility and reputational effects will establish new external sourcing activities more effectively and with more interesting partners, leading to a stronger innovative performance compared to their competitors that cannot benefit from strong visibility.

Based on these different arguments, we argue that CVC investments enhance the relationship between strategic alliances or M\&As and innovative performance. In other words, CVC investments are expected to be complementary to other modes of external technology sourcing.

Hypothesis 3. Corporate venture capital investments are complementary to other modes of external technology sourcing.

\section{DATA AND METHODS}

\section{A. Sample}

To test our hypotheses, we use a sample of firms that were active in the pharmaceutical industry between 1990 and 1997. The dataset was constructed in the following way. For each year of the observation period, the 200 largest innovative companies 
in the pharmaceutical and biotechnology industry were selected. Following Rothaermel and Hess [67] and Rothaermel and Thursby [68], companies active in pharmaceutics and biotechnology are those that are active in the following patent classes, defined by the USPTO: $424,435,436,514,530,536,800$, and 930. ${ }^{1}$ Large innovating firms are more likely to engage in external technology sourcing activities and are more likely to report them publicly [50]. Prior research on alliances and acquisitions has for that reason also focused on the largest companies in the industry [1], [31], [42], [50]. After selecting the companies with the largest cumulative number of patents in the relevant patent classes, research institutes and universities were removed from the sample. Next, the remaining sample was manually checked for parents and affiliates using Dun \& Bradstreet's Who Owns Whom, which were then aggregated on parent company level. We will refer to these independent companies as "focal firms," to distinguish them from their partners.

Next, we have gathered information on all the venture capital investments, technology alliances, minority holdings, joint ventures, and merger and acquisitions of these firms during the period $1985-1996,{ }^{2}$ as well as patent data and financial information. Corporate venture capital data were derived from the Thomson VentureXpert database, data concerning alliances and joint ventures were obtained from the MERIT-CATI Databank on Cooperative Agreements and Technology Indicators [33], and we used Thomson ONE Banker to collect information regarding the companies' M\&A activity. Because both the collected alliances and corporate venture capital investments have a strong technology component, we included only technology related M\&As in our sample, following the method by Ahuja and Katila [2]. The final sample comprises 4,302 technology sourcing deals.

Patent information until 2003 was collected for all firms included in our sample using data from the US Patent and Trademark Office. Because the US Patent and Trademark Office grants patents both on subsidiary as well as on parent company level [64], and the organizational level on which patents are applied for differs between companies, we consolidated the patents on parent company level for each observation year, using Who Owns Whom by Dun \& Bradstreet. In addition to that, we gathered financial data using Worldscope, including sales and research and development expenses.

\section{B. Variables}

1) Dependent Variable: Our dependent variable, innovative performance, measures the innovation output of the focal firms.

\footnotetext{
${ }^{1}$ Description of the patent classes is as follows: 424: drug, bioaffecting and body treating compositions; 435 : chemistry: molecular biology and microbiology; 436: chemistry: analytical and immunological testing; 514: drug, bioaffecting and body treating compositions; 530: chemistry: natural resins or derivatives; peptides or proteins; lignins or reaction products thereof; 536: organic compounds; 800: multicellular living organisms and unmodified parts thereof and related processes; 930: peptide or protein sequence.

${ }^{2}$ Longer time lags are used because of the use of patent citations (a patent can only be cited after it has been issued which takes, on average, 3 years for the firms in our sample). In order to avoid right censoring of the data, we take 1997 as the last observation year for the dependent variable.
}

Patent counts have often been criticized as an indicator for innovative performance because this measure gives an identical weight to each patent application, and hence, does not capture the importance of the innovation [34], [76]. In order to capture the value of innovation, we therefore use patent citations, or weighted patent counts [76]. Weighted patent counts (WPC) is also a count variable, but each patent $i$ is now weighed according to the subsequent citations $C_{i}$ it receives, assuming that more important patents receive more citations and vice versa. Weighted patent counts for $n$ patents applied for in year $t$ can be calculated following the formula [76]:

$$
W P C_{t}=\sum_{i=1}^{n_{t}}(1+C i)
$$

Patent citations were collected until 2003, and in order to avoid right-censoring problems, we took 1997 as the last year of the observation period. As the time horizon of the dataset is limited and we are not able to observe all possible forward citations for each patent, we use the simulated cumulative distribution lags developed by Hall et al. [36] to estimate the total number of citations each patent is likely to receive. The simulated cumulative distribution lags show the yearly distributions of the total citations a patent is likely to receive. Using these distribution lags, we are able to estimate the total number of citations a patent will receive, based on the cumulative number of citations till 2003, the last year of our observation period.

In addition, we studied the additive effects of CVC investments on exploratory innovation, including novel, emerging, and pioneering technologies [3] as independent variables. The variable novel technologies is measured as the number of new technology classes that are entered in the year of observation. Emerging technologies is calculated as the number of patents that cite technologies that are, on average, less than 2 years old. Finally, pioneering technologies is calculated as the number of patents that cite no other patents.

2) Independent Variables: Hypothesis 1 predicts a direct relationship between CVC investments and innovative output. Therefore, for every observation in year $t$, we counted the number of CVC investments in the 5 years prior to the observation year $(t-1$ to $t-5)$. This moving window approach is considered to be an appropriate timeframe during which the existing portfolio of external technology activities is likely to have an influence on the current technological performance of a firm [31], [47], [72]. This line of reasoning has been confirmed by a robustness check in which we also computed the independent variables using a 4-year window. The 4 years and 5 years lagged variables were highly correlated ( $r>0.95$ in all cases) and the estimation results using the 4-year lagged variables were very similar to the results presented in this paper.

Next, we are interested in the additivity and complementarity of CVC investments vis-à-vis the other modes for technology sourcing such as strategic alliances and M\&A activities. Accordingly, we have calculated the number of nonequity alliances, equity alliances, and $M \& A s$ as additional variables. Equity alliances are strategic technology partnerships that involve the use of equity investments, such as joint ventures and minority 
TABLE I

DESCRIPTIVE STATISTICS AND CORRELATIONS

\begin{tabular}{|c|c|c|c|c|c|c|c|c|c|c|c|c|c|}
\hline & & Mean & S.D. & 1 . & 2. & 3. & 4. & 5 . & 6. & 7. & 8. & 9. & 10. \\
\hline 1. & Weighted patent counts & 1360.83 & 2145.19 & & & & & & & & & & \\
\hline 2. & Novel technologies & 3.70 & 3.30 & .61 & & & & & & & & & \\
\hline 3. & Emerging technologies & 8.32 & 16.79 & .65 & .47 & & & & & & & & \\
\hline 4. & Pioneering technologies & 6.56 & 10.65 & .35 & .29 & .57 & & & & & & & \\
\hline 5. & Size & 9.61 & 2.19 & .07 & .07 & .17 & .10 & & & & & & \\
\hline 6. & R\&D intensity & 0.10 & 0.24 & -.08 & -.15 & -.06 & -.03 & -.43 & & & & & \\
\hline 7. & Technological capital & 0.61 & 0.82 & .82 & .55 & .77 & .50 & .16 & -.12 & & & & \\
\hline 8. & Non-equity alliances & 3.75 & 5.84 & .46 & .36 & .33 & .39 & .00 & -.07 & .57 & & & \\
\hline 9. & Equity alliances & 1.85 & 2.67 & .38 & .31 & .27 & .31 & .02 & -.09 & .46 & .74 & & \\
\hline 10. & M\&As & 2.19 & 2.99 & .36 & .34 & .21 & .22 & .00 & -.14 & .45 & .50 & .54 & \\
\hline 11. & CVC investments & 0.46 & 1.51 & .22 & 21 & .09 & .07 & -.06 & .00 & .13 & .29 & .26 & 13 \\
\hline
\end{tabular}

holdings (less than $50 \%$ ownership). For every observation year $t$, we counted the number of times each technology sourcing mode was established in the five years prior to the observation year $(t-1$ to $t-5)$.

3) Control Variables: We included technological capital or patent stock as a measure of a firm's technological strength (e.g., [21], [47], and [80]). This variable is computed as the cumulative number of patents applied for by the focal firm in the 5 years prior to the observation year $t$. A moving window of 5 years is the appropriate time frame for assessing technological impact [1], [41], [65], [73]. Studies about R\&D depreciation [29], [30] suggest that knowledge capital depreciates sharply, losing most of its economic value within 5 years.

$\mathrm{R} \& \mathrm{D}$ expenditures can be seen as a means to generate absorptive capacity necessary to benefit from external technology sourcing. We therefore include $R \& D$ intensity ( $R \& D$ expenditures as a percentage of sales) as a control variable. In addition to that, we controlled for size (natural logarithm of sales) and we introduced yearly dummy variables to capture eventual changes in patent application levels, legal system, or economic environment. The control variables size and $R \& D$ intensity are lagged by 1 year.

\section{Method}

The dependent variable of this study, weighted patent counts, is a count variable. Although Poisson models are often used to estimate count outcomes, the model, in practice, rarely fits due to overdispersion [57]. Because our data show significant evidence of overdispersion (i.e., the variance largely exceeds the mean-see Table I), a negative binomial regression model seems to be more appropriate [10], [38], [72]. The negative binomial model for panel data is estimated using the XTNBREG command in STATA.

We furthermore employed a Hausman specification test [37] on the baseline model to determine the choice between a random and a fixed effects model. The Hausman test was strongly significant, indicating that a fixed effects model is the appropriate model for this analysis. Because fixed effects models do not allow the inclusion of time-invariant variables, region dummies were not included in the analysis. ${ }^{3}$

In addition, given the exploratory nature of CVC investments, we have carried out some additional analyses, using exploratory

\footnotetext{
${ }^{3}$ We have also performed a random-effects analysis including industry and region dummies and found very similar results, underscoring the robustness of the models presented in this paper.
}

innovation measures as dependent variables. Different models were estimated, using pioneering, emerging, and novel technologies as dependent variables. To enhance interpretability, we have used a negative binomial model with fixed effects for these analyses as well.

\section{RESULTS}

The descriptive statistics and correlations between the independent variables are presented in Table I. As shown in Table I, there are high correlations among the control variables representing the various forms of external technology sourcing (nonequity alliances, equity alliances, and M\&As). These high correlations are a first indicator for the existence of complementarity (e.g., [5], [25], and [54]) and they are in line with earlier findings by Arora and Gambardella [5] and Cassiman and Veugelers [12]. However, a positive correlation among different strategies is not a necessary, nor a sufficient condition to assume complementarity [6], [12].

These positive correlations also stress the importance of estimating the effects of CVC investments while including other external sourcing modes in the analysis. Since external technology sourcing strategies are highly correlated, the positive effects of CVC investments found in earlier studies might be the effect of other, unobserved factors rather than stemming directly from CVC investments.

Table II presents the results of the negative binomial regressions, using weighted patent counts as a dependent variable. Table III shows the results for the creation of novel, emerging, and pioneering technologies, respectively. The first models present the baseline model, including only the control variables size, $R \& D$ intensity, and technological capital. Model 2 in Table II, and Models 2, 6, and 10 in Table III present the effect of CVC investments on innovation outcomes, without controlling for other modes of external technology sourcing, followed by a model including the squared term to test for a possible curvilinear relationship between CVC investments and performance. Finally, in Models 4 and 5 in Table II, and Models 4, 8, and 12 in Table III, we include the other technology sourcing modes, i.e., nonequity alliances, equity alliances, and $M \& A s$ in the analysis. These variables represent the stock of other external sourcing activities undertaken by the investing firm in the 5 years prior to the year of observation. ${ }^{4}$

\footnotetext{
${ }^{4}$ Although the high correlations among the different sourcing strategies stress our belief that most diversified firms are involved in a large number of externa
} 
TABLE II

Fixed EFFects Panel Estimation Results (Weighted Patent Counts) ${ }^{\mathrm{c}, \mathrm{d}}$

\begin{tabular}{|c|c|c|c|c|c|}
\hline & $\begin{array}{l}\text { Model I } \\
\text { WPC }\end{array}$ & $\begin{array}{l}\text { Model } 2 \\
\text { WPC } \\
\end{array}$ & $\begin{array}{l}\text { Model } 3 \\
\text { WPC } \\
\end{array}$ & $\begin{array}{l}\text { Model } 4 \\
\text { WPC } \\
\end{array}$ & $\begin{array}{l}\text { Model } 5 \\
\text { WPC } \\
\end{array}$ \\
\hline Constant & $\begin{array}{l}0.678 * * * \mathrm{~b} \\
(0.242)^{\mathrm{a}}\end{array}$ & $\begin{array}{l}0.587 * * \\
(0.243)\end{array}$ & $\begin{array}{l}0.559 * * \\
(0.243)\end{array}$ & $\begin{array}{l}0.713^{* * *} \\
(0.245)\end{array}$ & $\begin{array}{l}0.723 * * * \\
(0.244)\end{array}$ \\
\hline Size & $\begin{array}{l}0.113 * * * \\
(0.0237)\end{array}$ & $\begin{array}{l}0.118^{* * *} \\
(0.0236)\end{array}$ & $\begin{array}{l}0.119 * * * \\
(0.0236)\end{array}$ & $\begin{array}{l}0.0986 * * * \\
(0.0240)\end{array}$ & $\begin{array}{l}0.0980 * * * \\
(0.0240)\end{array}$ \\
\hline R\&D intensity & $\begin{array}{l}0.113 \\
(0.269)\end{array}$ & $\begin{array}{l}0.167 \\
(0.268)\end{array}$ & $\begin{array}{l}0.180 \\
(0.268)\end{array}$ & $\begin{array}{l}0.105 \\
(0.270)\end{array}$ & $\begin{array}{l}0.100 \\
(0.270)\end{array}$ \\
\hline Technological capital (x1000 patents) & $\begin{array}{l}0.366^{* * * *} \\
(0.0381)\end{array}$ & $\begin{array}{l}0.392^{* * * *} \\
(0.0381)\end{array}$ & $\begin{array}{l}0.404 * * * \\
(0.0386)\end{array}$ & $\begin{array}{l}0.313^{* * *} * \\
(0.0453)\end{array}$ & $\begin{array}{l}0.306 * * * \\
(0.0446)\end{array}$ \\
\hline Non-equity alliances & & & & $\begin{array}{l}0.0146 * * * \\
(0.00396)\end{array}$ & $\begin{array}{l}0.0148^{* * *} \\
(0.00395)\end{array}$ \\
\hline Equity alliances & & & & $\begin{array}{l}0.0156^{*} \\
(0.00868)\end{array}$ & $\begin{array}{l}0.0164 * \\
(0.00866)\end{array}$ \\
\hline M\&As & & & & $\begin{array}{l}0.0132 * \\
(0.00753)\end{array}$ & $\begin{array}{l}0.0133^{*} \\
(0.00756)\end{array}$ \\
\hline $\begin{array}{l}\text { CVC investments } \\
(\mathrm{CVC} \text { investments })^{2}\end{array}$ & & $\begin{array}{l}0.0437 * * * \\
(0.0121)\end{array}$ & $\begin{array}{l}0.0764 * * * \\
(0.0221) \\
-0.00365 * \\
(0.00221)\end{array}$ & $\begin{array}{l}0.0386^{*} \\
(0.0226) \\
-0.00170 \\
(0.00227)\end{array}$ & $\begin{array}{l}0.0244^{*} \\
(0.0129)\end{array}$ \\
\hline $\begin{array}{l}\text { Wald Chi2 } \\
\text { Log Likelihood } \\
\text { LR-test }\end{array}$ & $\begin{array}{l}288.63 * * * \\
-4696.84\end{array}$ & $\begin{array}{l}307.90^{* * *} \\
-4691.39 \\
10.90^{* * *}\end{array}$ & $\begin{array}{l}316.27 * * * \\
-4689.91 \\
2.97 *\end{array}$ & $\begin{array}{l}384.37 * * * \\
-4673.28 \\
33.25^{* * *}\end{array}$ & $\begin{array}{l}380.41^{* * *} \\
-4673.58 \\
35.63^{* * *} \mathrm{e}\end{array}$ \\
\hline
\end{tabular}

${ }^{\mathrm{a}}$ Standard errors in parentheses.

$\mathrm{b}_{*}$ significant at $10 \% ; * *$ significant at $5 \% ; * *$ significant at $1 \%$

${ }^{c}$ Number of observations $=792$; number of firms $=109$.

${ }^{\mathrm{d}}$ Year dummy variables were included but are not shown.

${ }^{\circ}$ Compared to Model 2.

TABLE III

FiXed EfFects Panel Estimation Results (Pioneering, Novel, and EMERGing TechnOlogies) ${ }^{\mathrm{c}, \mathrm{d}}$

\begin{tabular}{|c|c|c|c|c|c|c|c|c|c|c|c|c|}
\hline & $\begin{array}{l}\text { Model 1 } \\
\text { Novel } \\
\text { technologies }\end{array}$ & $\begin{array}{l}\text { Model 2 } \\
\text { Novel } \\
\text { technologies }\end{array}$ & $\begin{array}{l}\text { Model } 3 \\
\text { Novel } \\
\text { technologies }\end{array}$ & $\begin{array}{l}\text { Model 4 } \\
\text { Novel } \\
\text { technologies }\end{array}$ & $\begin{array}{l}\text { Model } 5 \\
\text { Emerging } \\
\text { technologies }\end{array}$ & $\begin{array}{l}\text { Model } 6 \\
\text { Emerging } \\
\text { technologies }\end{array}$ & $\begin{array}{l}\text { Model } 7 \\
\text { Emerging } \\
\text { technologies }\end{array}$ & $\begin{array}{l}\text { Model } 8 \\
\text { Emerging } \\
\text { technologies }\end{array}$ & $\begin{array}{l}\text { Model 9 } \\
\text { Pioneering } \\
\text { technologies }\end{array}$ & $\begin{array}{l}\text { Model 10 } \\
\text { Pioneering } \\
\text { technologies }\end{array}$ & $\begin{array}{l}\text { Model 11 } \\
\text { Pioneering } \\
\text { technologies }\end{array}$ & $\begin{array}{l}\text { Model 12 } \\
\text { Pioneering } \\
\text { technologies }\end{array}$ \\
\hline Constant & $\begin{array}{l}0.00662 \\
(1.041)\end{array}$ & $\begin{array}{l}-0.00782 \\
(1.038)\end{array}$ & $\begin{array}{l}0.0509 \\
(1.039)\end{array}$ & $\begin{array}{l}0.557 \\
(1.103)\end{array}$ & $\begin{array}{l}-2.709^{* * * *} \\
(0.703)\end{array}$ & $\begin{array}{l}-2.744 * * * \\
(0.704)\end{array}$ & $\begin{array}{l}-2.829^{* * * * * *} \\
(0.710)\end{array}$ & $\begin{array}{l}-2.294 * * * \\
(0.737)\end{array}$ & $\begin{array}{l}-2.099 * * * \\
(0.809)\end{array}$ & $\begin{array}{l}-2.029 * * \\
(0.792)\end{array}$ & $\begin{array}{l}-2.014^{* *} \\
(0.785)\end{array}$ & $\begin{array}{l}-1.181 \\
(0.791)\end{array}$ \\
\hline Size & $\begin{array}{l}0.354 * * * \\
(0.112)\end{array}$ & $\begin{array}{l}0.352 * * * \\
(0.111)\end{array}$ & $\begin{array}{l}0.344 * * * \\
(0.111)\end{array}$ & $\begin{array}{l}0.287 * * \\
(0.117)\end{array}$ & $\begin{array}{l}0.478 * * * \\
(0.0816)\end{array}$ & $\begin{array}{l}0.475 * * * \\
(0.0821)\end{array}$ & $\begin{array}{l}0.479 * * * \\
(0.0831)\end{array}$ & $\begin{array}{l}0.416 * * * \\
(0.0865)\end{array}$ & $\begin{array}{l}0.418 * * * \\
(0.0921)\end{array}$ & $\begin{array}{l}0.404 * * * \\
(0.0901)\end{array}$ & $\begin{array}{l}0.400^{* * *} \\
(0.0892)\end{array}$ & $\begin{array}{l}0.300^{* * * *} \\
(0.0884)\end{array}$ \\
\hline R\&D intensity & $\begin{array}{l}0.000879 \\
(0.561)\end{array}$ & $\begin{array}{l}0.00586 \\
(0.561)\end{array}$ & $\begin{array}{l}-0.00965 \\
(0.561)\end{array}$ & $\begin{array}{l}-0.178 \\
(0.579)\end{array}$ & $\begin{array}{l}1.143 * * \\
(0.447)\end{array}$ & $\begin{array}{l}1.161^{* * *} \\
(0.448)\end{array}$ & $\begin{array}{l}1.191^{* * * *} \\
(0.449)\end{array}$ & $\begin{array}{l}0.927^{* *} \\
(0.459)\end{array}$ & $\begin{array}{l}1.111 * * \\
(0.459)\end{array}$ & $\begin{array}{l}1.095^{* *} \\
(0.456)\end{array}$ & $\begin{array}{l}1.092^{* *} \\
(0.455)\end{array}$ & $\begin{array}{l}0.806^{*} \\
(0.458)\end{array}$ \\
\hline $\begin{array}{l}\text { Technological } \\
\text { capital (x1000 } \\
\text { patents) }\end{array}$ & 0.0349 & 0.0447 & 0.0622 & 0.0166 & $0.295 * *$ & $0.329 * * *$ & $0.387 * * *$ & $0.333 * * *$ & $0.334 * * *$ & $0.351^{* * *}$ & $0.358 * * *$ & $0.326 * * *$ \\
\hline $\begin{array}{l}\text { Non-equity } \\
\text { alliances }\end{array}$ & $(0.0990)$ & $(0.100)$ & $(0.102)$ & $\begin{array}{l}(0.101) \\
0.0148^{* *}\end{array}$ & $(0.0608)$ & $(0.0622)$ & $(0.0640)$ & $\begin{array}{l}(0.0675) \\
0.0149^{* * *}\end{array}$ & $(0.0962)$ & $(0.0962)$ & $(0.0964)$ & $\begin{array}{l}(0.103) \\
0.0210^{* * *}\end{array}$ \\
\hline Equity alliances & & & & $\begin{array}{l}(0.00698) \\
-0.0155 \\
(0.0143)\end{array}$ & & & & $\begin{array}{l}(0.00559) \\
0.0256^{* *} \\
(0.0120)\end{array}$ & & & & $\begin{array}{l}(0.00623) \\
0.0184 \\
(0.0143)\end{array}$ \\
\hline M\&As & & & & $\begin{array}{l}0.00702 \\
(0.0116)\end{array}$ & & & & $\begin{array}{l}-0.0192^{*} \\
(0.0100)\end{array}$ & & & & $\begin{array}{l}-0.0178 \\
(0.0111)\end{array}$ \\
\hline $\begin{array}{l}\text { CVC investments } \\
(\text { CVC investments })^{2}\end{array}$ & & $\begin{array}{l}0.0123 \\
(0.0189)\end{array}$ & $\begin{array}{l}0.0439 \\
(0.0341) \\
-0.00356 \\
(0.00326)\end{array}$ & $\begin{array}{l}0.0105 \\
(0.0199)\end{array}$ & & $\begin{array}{l}0.0375^{* *} \\
(0.0167)\end{array}$ & $\begin{array}{l}0.132 * * * \\
(0.0304) \\
-0.0103 * * * \\
(0.00314)\end{array}$ & $\begin{array}{l}0.0773^{* *} \\
(0.0328) \\
-0.00746^{* *} \\
(0.00327)\end{array}$ & & $\begin{array}{l}0.0362^{* *} \\
(0.0177)\end{array}$ & $\begin{array}{l}0.0626^{*} \\
(0.0328) \\
-0.00262 \\
(0.00280)\end{array}$ & $\begin{array}{l}0.0142 \\
(0.0189)\end{array}$ \\
\hline Wald Chi2 & $29.62 * * *$ & $30.09 * * *$ & $31.52 * * *$ & $35.76 * * *$ & $104.25 * * *$ & $108.29^{* * * *}$ & $126.51^{* * * *}$ & $186.70^{* * *}$ & $99.28 * * *$ & $105.19^{* * *}$ & $106.86^{* * *}$ & $140.86^{* * *}$ \\
\hline $\begin{array}{l}\text { Log Likelihood } \\
\text { LR-test }\end{array}$ & -1273.97 & $\begin{array}{l}-1273.76 \\
0.42\end{array}$ & $\begin{array}{l}-1273.15 \\
1.23\end{array}$ & $\begin{array}{l}-1271.38 \\
0.17\end{array}$ & -1550.58 & $\begin{array}{l}-1548.22 \\
4.73^{* *}\end{array}$ & $\begin{array}{l}-1541.97 \\
12.50^{* * * *}\end{array}$ & $\begin{array}{l}-1531.99 \\
19.96^{* * * *}\end{array}$ & -1404.60 & $\begin{array}{l}-1402.61 \\
3.98^{* *}\end{array}$ & $\begin{array}{l}-1402.17 \\
0.90\end{array}$ & $\begin{array}{l}-1392.51 \\
19.31^{* * *}\end{array}$ \\
\hline
\end{tabular}

${ }^{\mathrm{a}} \mathrm{Standard}$ errors in parentheses.

b* significant at $10 \% ; * *$ significant at $5 \% ; * * *$ significant at $1 \%$.

Number of observations $=788 ; 766 ; 763$ resp.; number of firms $=107 ; 104 ; 103$ resp.

${ }^{\mathrm{d}}$ Year dummy variables were included but are not shown.

Hypothesis 1 predicted an overestimation of the positive effects of CVC investments and subsequent innovation output, as a result of omitted variable bias. Models 2 and 3 in Table II show that prior CVC investments have a positive, but curvilinear effect on weighted patent counts, which is in line with prior studies [82]. The results furthermore indicate the possi-

technology sourcing agreements, at the same time, they also indicate possible multicollinearity problems. However, the results in Model 3 indicate that, despite the high correlation among the independent variables (Table I), $t$-statistics remain significant indicating that multicollinearity is not a problem here. As a robustness check, we have performed several additional analyses where 1) the independent variables were included one by one and 2) where all governance modes were grouped into one stock variable. The results of these additional analyses are very similar to the results presented here; indicating that multicollinearity between the independent variables is not an issue in this paper. bility of an omitted variable bias when CVC investments are studied in isolation, as the magnitude of the direct effect of CVC investments on innovative performance decreases substantially when controlling for other modes of external technology sourcing (compare Models 2 and 3 to Models 4 and 5 in Table II). Moreover, the LR test statistics indicate that the models including the other modes for external technology sourcing (Models 4 and 5) have a significantly better fit than the model with only CVC investments included. These findings are corroborated by the results in Table III. In particular, compare Models 7 and 8, and Models 10 and 12 from Table III, which show that the positive effects of CVC investments on emerging and pioneering technologies, respectively, become smaller (and the significance slightly weaker) when the other sourcing modes 
are included. Together, these findings provide empirical support for Hypothesis 1.

Next, Hypothesis 2 states that CVC investments are additive to other modes of technology sourcing. The results in Tables II and III provide support for the additivity hypothesis (Hypothesis 2). Models 4 and 5 in Table II show that nonequity alliances, equity alliance, M\&As, and CVC investments are all significant and positively related to innovation output. The results in Table III provide varying results. Models 2, 3, and 4 show no significant effect for the use of CVC investments and the creation of novel technologies. This implies that CVC investments do not affect the generation of technologies that are new to the firm. Model 7 indicates that CVC investments are curvilinearly (inverted U-shaped) related to emerging technologies. Moreover, this effect holds when other modes for external knowledge sourcing are included (Model 8), indicating that CVC investments are indeed additive to other modes of technology sourcing when investing in emerging (or new) technologies. Finally, Models 10 and 11 show that CVC investments have a positive effect on the creation of pioneering technologies. However, the coefficient becomes insignificant when the other modes for external technology sourcing are included. We will elaborate on those findings in Section V.

\section{A. Complementarity}

Next, we analyze to what extent the different modes for external technology sourcing are complementary (Hypothesis 3). In order to estimate complementarity, there are two methods that can be found in the literature. First, there is the use of a production function approach to determine the effects of using particular combinations of external technology sourcing strategies on a firm's innovative performance [8], [12], [62]. Using this approach allows for a direct test of the complementarity constraints, by testing multiple inequality constraints simultaneously [62]. First, for each possible combination of strategies, a corresponding dummy variable is included to capture whether or not the firm is involved in that particular combination of strategies. These dummy variables are then included in a regression analysis, and based on the estimates following from the regression analysis, a number of inequality restrictions can be tested. A more detailed explanation of this method can be found in Mohnen and Röller [62].

Another method that can be found in the literature is the use of pairwise interaction terms to assess complementarity [9], [11], [43], [56]. Using interaction terms allows for the estimation of the amount of interaction between two or more practices, whereas using a production function with dummies only provides an insight into particular combinations but remains silent on the magnitude of the increasing gains of using the one while already performing the other. However, pairwise interaction terms assume that complementarity exists on the level of pairs of variables, and does not pick up the effects of multilateral interactions [83]. In addition, as pairwise interactions are also used to estimate the "fit" between two variables or the "moderating" effect of one variable on the performance relationship of another variable, it remains unclear whether the significance of
TABLE IV

COMBINATIONS OF STRATEGIES USED By FocAl FiRMS (FIRM-YEAR OBSERVATIONS)

\begin{tabular}{lc|r}
\hline & $\left(x_{1}, \boldsymbol{x}_{2}, \boldsymbol{x}_{3}, \boldsymbol{x}_{4}\right)$ & Total \\
\hline None & $(0,0,0,0)$ & 206 \\
& & \\
Non-equity alliances & $(1,0,0,0)$ & 87 \\
Equity alliances & $(0,1,0,0)$ & 31 \\
M\&As & $(0,0,1,0)$ & 79 \\
CVC investments & $(0,0,0,1)$ & 8 \\
& & \\
Non-equity alliances \& equity alliances & $(1,1,0,0)$ & 80 \\
Non-equity alliances \& M\&As & $(1,0,1,0)$ & 61 \\
Non-equity alliances \& CVC investments & $(1,0,0,1)$ & 10 \\
Equity alliances \& M\&As & $(0,1,1,0)$ & 60 \\
Equity alliances \& CVC investments & $(0,1,0,1)$ & 0 \\
M\&As and CVC investments & $(0,0,1,1)$ & 1 \\
& $(1,1,1,0)$ & 231 \\
Non-equity alliances, equity alliances, \& M\&As & $(1,1,0,1)$ & 11 \\
Non-equity alliances, equity alliances, \& CVC investments & $(1,0,1,1)$ & 10 \\
Non-equity alliances, M\&As, \& CVC investments & $(0,1,1,1)$ & 0 \\
Equity alliances, M\&As, \& CVC investments & $(1,1,1,1)$ & 98 \\
Non-equity alliances, equity alliances, M\&As \& CVC investments & & \\
\hline
\end{tabular}

the interaction term reflects complementarity rather than "fit" or "moderating" effects [75].

Because the focus of this paper is on the complementarity of CVC investments vis-à-vis other strategies in the external technology sourcing portfolio, we use a production function with dummies, rather than pairwise interaction terms, to estimate complementarity. Following prior studies, we have defined dummy variables indicating the activity of the firms in our sample with regards to possible combinations of strategies. Table IV provides an overview of the possible combinations and the number of firm-year observations indicating involvement in that particular set of external sourcing modes, using a 5-year moving window.

Table IV shows that the majority of firms is involved in a combination of nonequity alliances, equity alliances, and M\&As. Combining these three strategies with CVC investment appears to be a common strategy as well, as is indicated by 98 firmyear observations depicting this portfolio. Assuming that firms optimize their portfolio, these figures give some indication concerning additivity and complementarity as apparently firms who invest in CVC investments are most likely to do so while simultaneously investing in other modes of technology sourcing. We also find pairwise combinations between nonequity and equity alliances and between these two external sources of technology and acquisitions. Pairwise combinations with CVC investments as well as triads including CVC investments seem to be less popular among the firms in the database.

Next, these dummy variables are included in a negative binomial regression model in order to estimate the effect of particular combinations of strategies on the innovation performance of firms. The results are shown in Table V.

The results of the regression analysis presented in Model 1 in Table $\mathrm{V}$ indicate that combining nonequity alliances with equity alliances or M\&As positively affect the innovation output of firms. Moreover, the results suggest that combining nonequity alliances with equity alliances and M\&As, and a strategy combining the four external technology sourcing modes also positively affect innovative performance. The results in Models 1 and 2 also indicate that using only CVC investments as a way to get access to external technology does not affect the innovative 
TABLE V

Fixed EFFects Panel Estimation Results, Using Dummy Variables For Possible Combinations of STRATEGIES ${ }^{\mathrm{c}, \mathrm{d}}$

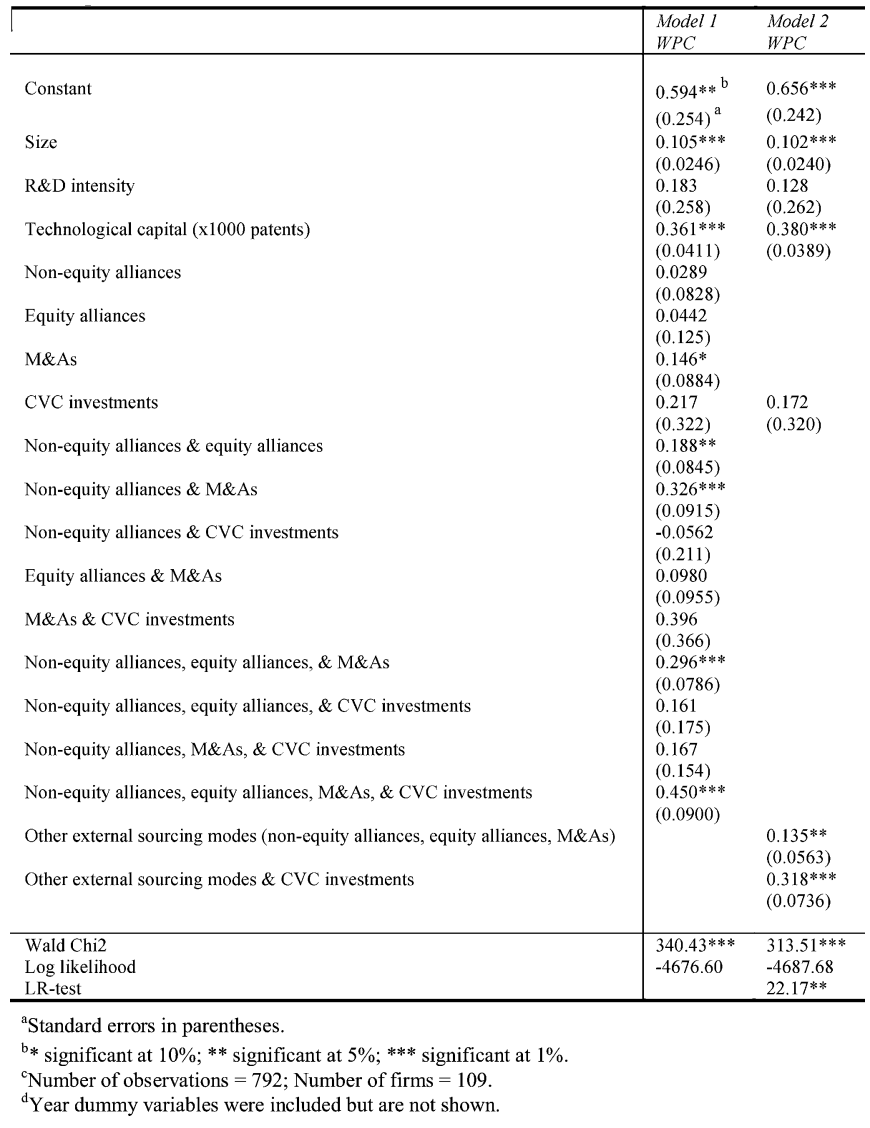

performance of firms. One-sided Wald tests furthermore show that the coefficient of using a combination of nonequity alliances, equity alliances, M\&As, and CVC investments is greater than the coefficient for using a combination of nonequity alliances, equity alliances, and M\&As but no CVC investments. This indicates that CVC investments are additive to nonequity alliances, equity alliances, and M\&As when used simultaneously, thereby providing additional support for Hypothesis 2. A portfolio consisting of CVC investments next to the more traditional modes for external technology sourcing has a positive effect on innovation performance.

However, these results do not yet indicate the existence of complementarity between the different external sourcing modes. In order to test for complementarity using the results from a production function model, a set of multiple inequality restrictions needs to be tested simultaneously (for an overview and explanation, see Mohnen and Röller [62] and Belderbos et al. [8]). In order to conduct the complementarity tests, one needs to have coefficient estimates of all possible strategies. Unfortunately, our dataset does not include observations for firms who have invested solely in CVC and equity alliances, or CVC, equity alliances, and M\&As (see Table IV). Moreover, there is only one observation for the combination M\&A and CVC investments. Hence, we are not able to follow the direct test for complementarity as suggested by the authors mentioned earlier. Therefore, we have also estimated a model using a single dummy variable for all other technology sourcing strategies (nonequity alliances, equity alliances, and/or M\&As). The results of this analysis are presented in Model 2 of Table V. Firms that only tap into external technology sources through CVC investments are not performing better than other companies - this contrasts with the positive impact of other technology sourcing modes. However, CVC investments in combination with other technology sourcing modes improve firms' innovation performance significantly. With only two groups of external technology modes, we need to test only one inequality constraint: $(1,1)+(0,0)-(1,0)-(0,1) \geq 0$. We have tested this inequality constraint using a Wald test. The result of this test shows that this inequality constraint holds, and thus, indicates that CVC investments are complements to other governance modes. ${ }^{5}$ This result confirms Hypothesis 3. CVC investments are not only additive to other modes for external technology sourcing; they can also be regarded as complementary. The implications of these findings will be discussed in Section V.

\section{DISCUSSION}

In this paper, we have examined how different modes for external technology sourcing affect the innovative performance of investing firms. Focusing on CVC investments, which are a relatively new vehicle for technology sourcing, we have estimated the direct effect of these investments on innovation output followed by an investigation of the effects when these investments are combined with the more traditional ways of technology sourcing, such as nonequity alliances, equity alliances, and M\&As. We have argued that CVC investments are both additive as well as complementary to other technology sourcing modes. They are additive because they all target different types of knowledge and are complementary too because of the specific knowledge and experience spillovers associated with external knowledge acquisition.

The results confirm the findings of prior studies that CVC investments have a positive and even curvilinear effect on subsequent innovative performance (e.g., [21] and [82]). When not controlling for other technology sourcing modes, the relationship appears to be inverted U-shaped, while the squared term becomes insignificant when the other modes are included in the model. Next, the results of this study indicate that including other strategies for technological search provides a richer explanation of the role of different modes for external technology sourcing and, as a result, that the effects of CVC investments should not be studied in isolation. The results presented in Models 3 and 4 in Table II indicate the existence of a potential omitted variable bias and stress the importance of including the whole portfolio of technology sourcing modes that a company has at its disposal.

The results in this study furthermore show the role of CVC investments in improving innovation performance when they are used jointly with other technology sourcing modes for external

\footnotetext{
${ }^{5}$ We first test the null hypothesis H0: $(1,1)+(0,0)-(1,0)-(0,1)=0$. This hypothesis is rejected $($ Chi2 $(1)=2.65 *)$. Next, we test if $(1,1)+(0,0)-(1,0)$ $-(0,1) \geq 0$ which is confirmed $(\mathrm{p}=0.95)$.
} 
knowledge acquisition. The results not only indicate that CVC investments are additive to other modes for technology sourcing, they also support the complementarity hypothesis when CVC investments are combined with other technology sourcing modes. Combining CVC investments with nonequity alliances, equity alliances, and M\&As positively affects the innovation rates of the investing firm. This supports our call for a portfolio approach to external technology acquisition research in general and CVC investment research in particular. More specifically, firms that have a diversified external sourcing portfolio are likely to benefit from their investments in different external knowledge sourcing modes.

Finally, the results of this study indicate that CVC investments are particularly interesting when a firm seeks to invest in the creation of pioneering and emerging technologies. The results in Table II show no relationship between CVC investments and the creation of novel technologies, indicating that CVC investments are not well-suited to explore into new technological domains. This is in line with Keil et al. [50] who showed that the benefits from investing in CVC are greatest when investments are made in related industries. Furthermore, CVC investments are found to be more impactful when firms seek to operate on the forefront of technological development. Some prior research has shown the benefits of CVC investment for exploratory inter-firm learning [70], thus implying that CVC investments are an important vehicle to enable the investing firm to operate on the technological frontier by developing newly emerging technologies.

This study contributes to the existing body of research in a number of ways. First, we combined the different modes of technology cooperation a company can use to get access to external knowledge in one single model (including CVC investments, nonequity alliances, equity alliances, and M\&As). Although prior research has extensively investigated the performance effects of CVC investments, strategic alliances, and M\&As separately, studies combining different modes are relatively scarce (exceptions are [50], [87]). Since most large firms are engaged in different technology partnerships at the same time, henc including all those possible technology sourcing strategies in one model provides a richer description of the dynamics when firms pursue a more open way of innovation. By doing so, this paper also contributes to the increasing body of research on portfolio diversity (e.g., [46], [59]).

Additionally, this paper sheds more light on the role of CVC investments, by stressing the unique benefits of these investments for the overall innovation performance of firms, as well as for the creation of exploratory innovation. Moreover, the results show how CVC investments can increase innovation performance when used in combination with the other modes of technology partnering, especially when used simultaneously with technology sourcing modes that target a more mature type of technology as opposed to the relatively new technologies that are aimed at through use of CVC investments.

\section{A. Implications and Future Research}

The findings of this study have important implications for management. First, they show that CVC investments can have a positive effect on a firm's subsequent innovative performance. Moreover, the results indicate the importance of CVC investments for exploratory innovation. Investing in CVC, next to the traditional modes of technology sourcing, can help or even make a difference for the subsequent creation of pioneering and emerging technologies. This implies that managers should carefully consider the motives behind investing in CVC, and the type of exploration that is sought.

Moreover, our findings suggest that CVC investments are highly complementary to other technology sourcing modes and should thus be used in conjunction with these modes rather than as a stand-alone investment strategy. In line with the imperative of open innovation [14], the current study stresses the advantages of the simultaneous use of different external sourcing modes at a particular point in time. Firms can improve their innovation performance by tapping simultaneously into different external technology sourcing mechanisms. In particular, the results of this study show that combining CVC investments with nonequity alliances, equity alliances, and M\&As positively affects the innovation rates of the investing firms. This implies that managers must carefully design their external sourcing portfolio. Particularly with an increasing interest nowadays for the use of CVC investments, managers need to be aware of the fact that CVC investments in early stage technologies are mostly beneficial when used as part of a broader technology sourcing portfolio and in combination with alliances and acquisitions of technologies that have already been further developed into marketable innovations. As a consequence, firms should think about external technology sourcing as a portfolio of investments, which requires a more centralized approach toward investment decisions.

Of course, this study is not without limitations. The first limitation regards the use of weighted patent counts to measure innovation output. Although patent indicators are widely used as a proxy for technological knowledge (e.g., [34] and [45]), it should be noted that there is also a significant share of knowledge created within the firm that cannot be captured in patent information. Furthermore, improvements in technology do not necessarily lead to a better financial performance of a company. Technological knowledge is not the same as successful new product introductions that lead to a surge in sales. In future research, more advanced combined measures of innovative performance, based on a combination of measures of new product introductions, patents, and licenses might further sophisticate our approach.

Another aspect regarding measurement is that we have measured CVC investments by counting the number of investments. For M\&As and alliances, we take on a similar approach. However, investments might differ significantly in terms of size. Some CVC investments amount to several hundred thousand dollars while others might account for investments of millions. Also comparing CVC investments or alliances to large M\&As that require investments of over 100 million dollars might create a potential bias in our results. Future research might enhance the value of our contribution by including the financial investments made in a particular mode.

In addition, the current study does not take into account the availability of internal human capital, for instance, in the form of 
star scientists [67]. Internal human capital may play an important role in the transfer and accumulation of external knowledge, and hence, in the innovation outcomes of external technology sourcing. Although the internal resources of firms are partially captured by their patents stocks and their R\&D expenditures, adding a measure of internal human capital may improve our understanding of how internal resources interact with external technology sourcing.

This study focuses on three main modes of external knowledge acquisition: strategic alliances, M\&As, and CVC investments. Firms, however, also employ other forms of external knowledge acquisition of which the most important one is licensing [77]. As a result, it would be logical to include licensing deals as another external technology sourcing mode. However, there are two main reasons not to do so. First, there is a practical problem; licensing deals are not documented in large-scale databases in a way that is compatible with the other technology sourcing modes. Second, there is a more fundamental reason. CVC investments, technology alliances, and acquisitions of small technology firms are instrumental in the development of new technologies in the focal company. Licensing agreements usually focus on the exchange of a ready-to-use technology. Hence, licensing is generally not geared toward the exploration of new technology, but rather focuses on the exploitation of existing technologies and will not allow the investing firm to build a competitive advantage based on its technological superiority. Similarly, arms-length technological contracting and licensing deals may be more interesting to improve noncore technologies, rather than to upgrade core technologies [15]. Future research could extend the current study by indicating the different roles these external technology sourcing modes play within an open innovation strategy. In this way, technology contracting and licensing could be integrated alongside alliances, acquisitions, and CVC investments as different channels to source technology from the outside.

Moreover, prior research in the field of open innovation has also indicated the importance of informal relationships, for instance, through professional conferences, meetings, fairs, and exhibitions [53]. These informal knowledge channels may also play an important role in the knowledge acquisition process (next to the formal collaboration efforts), as full understanding of different external sourcing mechanisms would benefit from including both formal as well as informal sources of knowledge and relationships.

Finally, in this paper, we have studied the impact of CVC investments on the innovative performance of firms and the extent to which these types of investments are complementary to other modes of external technology sourcing. However, we do not take a truly dynamic perspective on external technology acquisition. Alternative to analyzing the impact of external technology sourcing at the firm level, one could focus on the innovation project level by tracing the sequencing of different external technology modes over time; CVC investments are often regarded as a first-stage investment that might evolve in another type of mode when the technology further matures. CVC investments, strategic alliances, and M\&As are all part of a broader spectrum of technology insourcing that can be used sequentially when a technology becomes more mature. Future research into the dynamics of CVC investments as a first-stage investment should be conducted in order to get the full picture of how CVC investments as an initial investment in new technology projects can add value for firms. For instance, applying a real options logic to the external sourcing of technologies (e.g., [51]) might lead to the suggestion that strategic alliances or M\&As after an initial CVC investment improve innovative performance.

\section{REFERENCES}

[1] G. Ahuja, "Collaboration networks, structural holes, and innovation: A longitudinal study," Administ. Sci. Quart., vol. 45, pp. 425-455, 2000.

[2] G. Ahuja and R. Katila, "Technological acquisitions and the innovation performance of acquiring firms: A longitudinal study," Strateg. Manage. J., vol. 22, pp. 197-220, 2001.

[3] G. Ahuja and C. M. Lampert, "Entrepreneurship in the large corporation: A longitudinal study of how established firms create breakthrough ideas," Strateg. Manage. J., vol. 22, pp. 521-543, 2001.

[4] B. N. Anand and T. Khanna, "Do firms learn to create value? The case of alliances," Strateg. Manage. J., Special issue, vol. 21, pp. 295-315, 2000.

[5] A. Arora and A. Gambardella, "Complementarity and external linkages: The strategies of the large firms in biotechnology," J. Ind. Econ., vol. 38, pp. 361-379, 1990 .

[6] A. Arora, "Testing for complementarities in reduced form regressions: A note," Econ. Lett., vol. 50, pp. 51-55, 1996.

[7] J. A. C. Baum, T. Calabrese, and B. S. Silverman, "Don't go it alone: Alliance network composition and startups' performance in Canadian biotechnology," Strateg. Manage. J., vol. 21, pp. 267-294, 2000.

[8] R. Belderbos, B. Lokshin, and M. Carree, "Complementarity in R\&D cooperation strategies," Rev. Ind. Org., vol. 28, pp. 401-426, 2006.

[9] T. F. Bresnahan, E. Brynjolfsson, and L. M. Hitt, "Information technology, workplace organization, and the demand for skilled labor: Firm-level evidence," Quart. J. Econ., vol. 117, pp. 339-375, 2002.

[10] A. C. Cameron and P. K. Trivedi, Regression Analysis of Count Data Econometric Society Monograph No. 30. Cambridge, U.K.: Cambridge Univ. Press, 1998.

[11] E. Caroli and J. Van Reenen, "Skill-biased organizational change? Evidence from a panel of British and French establishments," Quart. J. Econ., vol. 116, pp. 1449-1492, 2001.

[12] B. Cassiman and R. Veugelers, "In search of complementarity in innovation strategy: Internal R\&D and external knowledge acquisition," Manage. Sci., vol. 52, pp. 68-82, 2006.

[13] H. W. Chesbrough, "Making sense of corporate venture capital," Harv. Bus. Rev., vol. 80, no. 3, pp. 4-11, 2002.

[14] H. W. Chesbrough, Open Innovation: The New Imperative for Creating and Profiting from Technology. Cambridge, MA: Harvard Business School Press, 2003.

[15] H. W. Chesbrough and K. Schwartz, "Innovating business models with co-development partnerships," Res. Technol. Manage., vol. 50, pp. 55-59, 2007.

[16] J. F. Christensen, M. H. Olesen, and J. S. Kjaer, "The industrial dynamics of open innovation. Evidence from the transformation of consumer electronics," Res. Policy, vol. 34, pp. 1533-1549, 2005.

[17] T. K. Das and B. Teng, "A resource-based theory of strategic alliances," J. Manage., vol. 26, pp. 31-61, 2000.

[18] S. De Celis and J. Lipinsky, "R\&D alliances and the effect of experience on innovation: A focus on the semiconductor industry," J. Leader. Org. Stud., vol. 14, pp. 26-37, 2007.

[19] A. P. De Man and G. M. Duysters, "Collaboration and innovation: A review of the effects of mergers, acquisitions and alliances on innovation,' Technovation, vol. 25, pp. 1377-1387, 2005.

[20] G. Dushnitsky and D. Lavie, "Interdependence in the evolution of interfirm networks: How alliances shape corporate venture capital in the software industry," presented at the 2007 West Coast Res. Symp. Technol. Entrepreneurship, Seattle, WA, 2008.

[21] G. Dushnitsky and M. J. Lenox, "When do incumbents learn from entrepreneurial ventures? Corporate venture capital and investing firm innovation rates," Res. Policy, vol. 34, pp. 615-639, 2005.

[22] G. Dushnitsky and M. J. Lenox, "When does corporate venture capital create firm value?" J. Bus. Venturing, vol. 21, pp. 753-772, 2006.

[23] J. H. Dyer, P. Kale, and H. Singh, "How to make strategic alliances work," Sloan Manage. Rev., vol. 42, no. 4, pp. 37-43, 2001 
[24] H. Ernst, P. Witt, and G. Brachtendorf, "Corporate venture capital as a strategy for external innovation: An exploratory empirical study," $R \& D$ Manage., vol. 25, pp. 233-242, 2005.

[25] T. M. Geraghty, "The factory system in the British industrial revolution: A complementarity thesis," Eur. Econ. Rev., vol. 51, pp. 1329-1350, 2007, 2011.

[26] V. A. Gilsing and B. Nooteboom, "Density and strength of ties in innovation networks, an analysis of multimedia and biotechnology," Eur. Manage. Rev., vol. 2, pp. 179-197, 2005.

[27] P. A. Gompers, "Corporations and the financing of innovation: The corporate venturing experience," Federal Reserve Bank of Atlanta Econ. Rev., Fourth Quarter, pp. 1-17, 2002.

[28] P. A. Gompers and J. Lerner, "The determinants of corporate venture capital success: Organizational structure, incentives, and complementarities," Cambridge, MA, Rep. NBER \#6725, 1998.

[29] Z. Griliches, "Issues in assessing the contribution of research and development to productivity growth," Bell J. Econ., vol. 10, pp. 92-116, 1979.

[30] Z. Griliches, Patents and Productivity. Chicago, IL: NBER, 1984.

[31] R. Gulati, "Social structure and alliance formation patterns: A longitudinal analysis," Administ. Sci. Quart., vol. 40, pp. 619-652, 1995.

[32] R. Gulati, "Alliances and networks," Strateg. Manage. J., vol. 19, pp. 293 $317,1998$.

[33] J. Hagedoorn, "Understanding the rationale of strategic technology partnering: Inter-organizational modes of cooperation and sectoral differences?" Strateg. Manage. J., vol. 14, pp. 371-385, 1993.

[34] J. Hagedoorn and M. M. A. H. Cloodt, "Measuring innovative performance: Is there an advantage in using multiple indicators," Res. Policy, vol. 32, pp. 1365-1379, 2003.

[35] J. Hagedoorn and G. M. Duysters, "The effect of mergers and acquisitions on the technological performance of companies in a high-tech environment," Technol. Anal. Strateg. Manage., vol. 14, pp. 67-85, 2002.

[36] B. H. Hall, A. Jaffe, and M. Trajtenberg, "The NBER patent citations file: Lessons, insights and methodological tools. NBER Working Paper Ser., \#8498, 2001

[37] J. Hausman, "Specification tests in econometrics," Econometrica, vol. 46, pp. 1251-1271, 1978

[38] J. Hausman, B. H. Hall, and Z. Griliches, "Econometric models for count data with an application to the patents-R\&D relationship," Econometrica, vol. 52, pp. 909-938, 1984.

[39] K. H. Heimeriks and G. Duysters, "Alliance capability as a mediator between experience and alliance performance: An empirical investigation into the alliance capability development process," J. Manage. Stud., vol. 44, pp. 25-49, 2007

[40] K. H. Heimeriks, W. Vanhaverbeke, and G. Duysters, "An exploratory study of learning mechanisms and differential performance in alliance portfolios," Strateg. Org., vol. 5, no. 4, pp. 373-408, 2007.

[41] R. Henderson and I. Cockburn, "Scale, scope and spillovers: The determinants of research productivity in drug discovery," Rand J. Econ., vol. 27, no. 1 , pp. 32-59, 1996

[42] M. A. Hitt, R. E. Hoskisson, R. D. Ireland, and J. S. Harrison, "Effects of acquisitions on R\&D inputs and outputs," Acad. Manage. J., vol. 34, pp. 693-706, 1991

[43] C. Ichniowski, K. Shaw, and G. Prennushi, "The effects of human resource management practices on productivity," Amer. Econ. Rev., vol. 87, pp. $291-313,1997$

[44] A. C. Inkpen, "Learning and knowledge acquisition through international strategic alliances," Acad. Manage. Rev., vol. 12, pp. 69-80, 1998.

[45] A. Jaffe and M. Trajtenberg, Patents, Citations and Innovations: A Window on the Knowledge Economy. Cambridge, MA: MIT Press, 2002.

[46] R. J. Jiang, Q. T. Tao, and M. D. Santoro,, "Alliance portfolio diversity and firm performance," Strateg. Manage. J., vol. 31, pp. 1136-1144, 2010.

[47] R. Katila and G. Ahuja, "Something old, something new: A longitudinal study of search behavior and new product introductions," Acad. Manage. J., vol. 45, pp. 1183-1194, 2002.

[48] R. Katila, J. Rosenberger, and K. Eisenhardt, "Swimming with sharks: Technology ventures and corporate relationships," Adminst. Sci. Quart., vol. 53, pp. 295-332, 2008.

[49] T. Keil, External Corporate Venturing: Strategic Renewal in Rapidly Changing Industries. Westport, CT: Quorum, 2003.

[50] T. Keil, M. Maula, H. Schildt, and S. Zahra, "The effect of governance modes and relatedness of external business development activities on innovative performance," Strateg. Manage. J., vol. 29, pp. 895-907, 2008.

[51] B. Kogut, "Joint ventures and the option to expand and acquire," Manage.
Sci., vol. 37, pp. 19-33, 1991

[52] S. Kortum and J. Lerner, "Assessing the contribution of venture capital to innovation," Rand J. Econ., vol. 31, no. 4, pp. 674-692, 2000.

[53] K. Laursen and A. Salter, "Open for innovation: The role of openness in explaining innovation performance among UK manufacturing firms," Strateg. Manage. J., vol. 27, no. 2, pp. 131-150, 2006.

[54] K. Laursen and V. Mahnke, "Knowledge strategies, firm types, and complementarity in human-resource practices," J. Manage. Govern., vol. 5 , pp. 1-27, 2001.

[55] D. Lavie, "The evolution and strategy of interconnected firms: A study of the Unysis alliance network," in Best Paper Proc. Acad. Manage. Conf. New Orleans, LA, 2004

[56] B. Lokshin, M. Carree, and R. Belderbos, "Testing for complementarity and substitutability in the case of multiple practices," METEOR, Maastricht Univ., 2007, Working paper.

[57] J. S. Long and J. Freese, Regression Models for Categorical Outcomes Using Stata, 2nd ed. College Station, TX: Stata Press, 2005.

[58] M. Lubatkin, "Mergers and the performance of the acquiring firm," Acad. Manage. Rev., vol. 8, no. 2, pp. 218-225, 1983 .

[59] J. P. M. McGill and M. D. Santoro, "Alliance portfolios and patent output: The case of biotechnology alliances," IEEE Trans. Eng. Manag., vol. 56, pp. 388-401, 2009.

60] I. McMillan, E. Roberts, V. Livada, and A. Wang, Corporate Venture Capital: Seeking Innovation and Corporate Growth. Gaithersburg, MD: National Inst. Standards and Technology, US Dept. Commerce, 2008

[61] P. Milgrom and J. Roberts, "The economics of modern manufacturing: Technology, strategy, and organization," Amer. Econ. Rev., vol. 80, pp. 511-528, 1990.

[62] P. Mohnen and LH. Röller, "Complementarities in innovation policy," Eur. Econ. Rev., vol. 49, pp. 1431-1450, 2005.

[63] S. Parise and A. Casher, "Alliance portfolios: Designing and managing your network of business-partner relationships," Acad. Manage. Executive, vol. 17, pp. 25-39, 2003.

[64] P. Patel and K. Pavitt, "The technological competencies of the world's largest firms: Complex and path-dependent, but not much variety," $R e-$ search Policy, vol. 26, pp. 141-56, 1997.

[65] J. M. Podolny and T. A. Stuart, "A role-based ecology of technological change," Amer. J. Sociol., vol. 100, no. 5, pp. 1224-1260, 1995.

[66] W. W. Powell, K. W. Koput, L. Smith-Doerr, and J. Owen-Smith, "Network position and firm performance: Organizational returns to collaboration in the biotechnology industry," Res. Sociol. Org., vol. 16, pp. 129-159, 1999.

[67] F. T. Rothaermel and A. M. Hess, "Building dynamic capabilities: Innovation driven by individual-, firm-, and network-level effects," Org. Sci. vol. 18, pp. 898-921, 2007.

[68] F. T. Rothaermel and M. Thursby, "The nanotech vs. the biotech revolution: Sources of incumbent productivity in research," Res. Policy, vol. 36, pp. 832-849, 2007.

[69] R. C. Sampson, "Experience effects and collaborative returns in R\&D alliances," Strateg. Manage. J., vol. 26, pp. 1009-1031, 2005.

[70] H. Schildt, M. Maula, and T. Keil, "Explorative and exploitative learning from external [1] corporate ventures," Entrepreneurship Theory Pract., vol. 29, pp. 493-515, 2005.

[71] R. Siegel, E. Siegel, and I. MacMillan, "Corporate venture capitalists Autonomy, obstacles and performance," J. Bus. Venturing, vol. 3, pp. 233 247, 1988.

[72] T. Stuart, "Interorganizational alliances and the performance of firms: A study of growth and innovation rates in a high-technology industry," Strateg. Manage. J., vol. 21, pp. 791-811, 2000.

[73] T. Stuart and J. Podolny, "Local search and the evolution of technological capabilities," Strateg. Manage. J., vol. 17, pp. 21-38, 1996.

[74] H. B. Sykes, "Corporate venture capital: Strategies for success," J. Bus. Venturing, vol. 5, pp. 37-47, 1990

[75] H. Tanriverdi and N. Venkatraman, "Knowledge relatedness and the performance of multibusiness firms," Strateg. Manage. J., vol. 26, pp. 97 119,2005

[76] M. Trajtenberg, "A penny for your quotes: Patent citations and the value of innovations," Rand J. Econ., vol. 21, no. 1, pp. 172-187, 1990.

[77] K.-H. Tsai and J.-C. Wang, "Inward technology licensing and firm performance: A longitudinal study," $R \& D$ Manage., vol. 37, no. 2, pp. 151-160, 2007.

[78] V. Van de Vrande, C. Lemmens, and W. Vanhaverbeke, "Choosing governance modes for external technology sourcing," $R \& D$ Manage., vol. 36 , 
no. 3, pp. 347-363, 2006.

[79] V. Van de Vrande, W. Vanhaverbeke, and G. Duysters, "External technology sourcing: The effect of uncertainty on governance mode choice," $J$. Bus. Venturing, vol. 24, pp. 62-80, 2009.

[80] W. Vanhaverbeke, G. Duysters, and N. Noorderhaven, "External technology sourcing through alliances or acquisitions: An analysis of the application-specific integrated circuits industry," Org. Sci., vol. 13, no. 6, pp. 714-733, 2002.

[81] F. Vermeulen and H. Barkema, "Learning through acquisitions," Acad. Manage. J., vol. 44, no. 3, pp. 457-476, 2001.

[82] A. Wadhwa and S. Kotha, "Knowledge creation through external venturing: Evidence from the telecommunications equipment manufacturing industry," Acad. Manage. J., vol. 49, no. 4, pp. 819-835, 2006.

[83] R. Whittington, A. Pettigrew, S. Peck, E. Fenton, and M. Conyon, "Change and complementarities in the new competitive landscape: A European panel study, 1992-1996," Org. Sci., vol. 10, no. 5, pp. 583-600, 1999.

[84] M. Zollo, J. J. Reuer, and H. Singh, "Interorganizational routines and performance in strategic alliances," $\mathrm{Org}$. Sci., vol. 13, no. 6, pp. 701-713, 2002.

[85] M. Zollo and J. J. Reuer, "Experience spillovers across corporate development activities," Wharton School, Univ. Pennsylvania, Philadelphia, 2001, Working Paper.

[86] T. W. Tong and Y. Li, "Real options and investment mode: Evidence from corporate venture capital and acquisition," Org. Sci., forthcoming, 2011.

[87] C. Nicholls-Nixon and C. Woo, "Technology sourcing and output of firms in a regime of encompassing technological change," Strategic Manage. J., vol. 24, pp. 651-666, 2003.

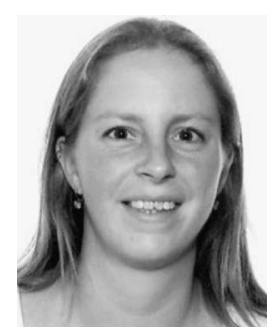

Vareska van de Vrande received the M.Sc. and $\mathrm{Ph} . \mathrm{D}$. degrees in industrial engineering and management science from Eindhoven University of Technology, Eindhoven, The Netherlands, in 2002 and 2007, respectively.

She is an Assistant Professor of strategic management at the Rotterdam School of Management, Erasmus University, Rotterdam, The Netherlands. She is also a Research Fellow at the Ecole Polytechnique Federale de Lausanne, Lausanne, Switzerland.

Her research focuses on several aspects of corporate entrepreneurship, including the use of different organizational forms for external technology sourcing, corporate venture capital investments, strategic alliances, joint ventures, and mergers and acquisitions. Her work has been published in international journals, such as the Journal of Business Venturing, the Journal of Product Innovation Management, Technovation, $R \& D$ Management, and Creativity and Innovation Management.

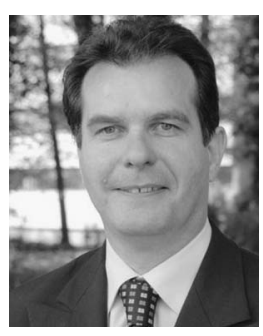

Wim Vanhaverbeke received the M.A. degree in economics from Kathlieke Universiteit Leuven, Belgium, in 1986, and the DBA degree in management, from IESE Barcelona (Universidad de Navarra), in 1995.

$\mathrm{He}$ is a Professor of strategy and innovation at the University of Hasselt, Hasselt, Belgium. He is also a Visiting Professor at ESADE, Barcelon, Spain, and the Vlerick Leuven Gent Management School, Hasselt.

$\mathrm{He}$ is the author or coauthor of several published articles in international journals including the Journal of Management Studies, Organization Science, Organization Studies, Strategic Organization, and the Journal of Business Venturing and Research Policy. He is the Co-Editor with Henry Chesbrough and Joel West of Open Innovation: Researching a New Paradigm and is currently involved in a number of research projects about managing and organizing open innovation.

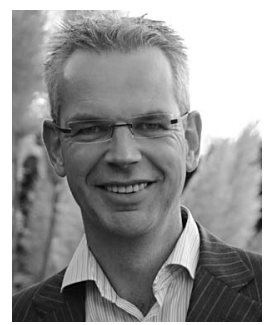

Geert Duysters received the Master's degree in business economics in 1990 and the Ph.D. degree in economics and business, in 1994, both from Maastricht University, Maastricht, The Netherlands.

$\mathrm{He}$ is a Full Professor of entrepreneurship and innovation at Tilburg, University, Tilburg, The Netherlands, and at the Eindhoven University of Technology, Eindhoven, The Netherlands.

$\mathrm{He}$ acts as the Scientific Director of the Brabant Center of Entrepreneurship, a joint center of Tilburg University and the Eindhoven University of Technology. His academic research mainly concerns innovation strategies, mergers and acquisitions, corporate entrepreneurship, and strategic alliances. He is the author or coauthor of more than 75 international refereed articles and book chapters on innovation. 